\title{
Teknik Fotografi dalam Sastra Realisme L'Adultera Karya Theodor Fontane
}

\author{
Kamelia Gantrisia \\ Program Studi Sastra Jerman Fakultas Ilmu Budaya Universitas Padjadjaran \\ Jalan Raya Bandung - Sumedang Km 21 Jatinangor 45363
}

\begin{abstract}
This research is entitled "Photography Approach in the Literary Work of Realism L'Adultera by Theodor Fontane". The aims of the research are to identify the descriptions found in literary work and the representation of photography criteria found in those descriptions. The methods employed in this research are formal method. The analysis is carried out by explaining the descriptions briefly and using them to identify parts of the text pointing to those descripstions. They are then analyzed by means of photography criteria from Heinz Buddermeier and Erwin Koeppen.

The result shows that the descriptions are concentrated on three types of setting descriptions: realm, interior, and building setting. In every description various description techniques which are similar to common techniques used in photography are found. They are observer's view transition, transition and/or regularity of observer's position, occuracy and sharpness of the object, static quality and object visual, and inequality of object setting.
\end{abstract}

Keywords: realism, description, photography

\begin{abstract}
ABSTRAK
Penelitian ini berjudul "Teknik Fotografi dalam karya Sastra Masa Realisme L'Adultera karya Theodor Fontane". Tujuan penelitian ini adalah untuk mengidentifikasikan deskripsideskripsi yang muncul dalam karya sastra dan mengkaji penggambaran-penggambaran fotografis dalam deskripsi-deskripsi tersebut. Metode yang dipergunakan adalah metode formal. Analisisnya dilakukan dengan cara menjabarkan secara singkat tentang deskripsi dalam karya sastra dan mempergunakannya untuk mengidentifikasikan bagian-bagian teks yang mengarah pada deskripsi. Bagian-bagian teks yang mengandung deskripsi tersebut selanjutnya dianalisis dengan bantuan kriteria-kriteria fotografi menurut Heinz Buddemeier dan Erwin Koppen.

Hasil penelitian ini menunjukkan bahwa deskripsi-deskripsi yang dimunculkan dalam karya dikonsentrasikan pada tiga jenis deskripsi latar, yaitu latar alam, interior, dan bangunan. Dalam setiap deskripsi ditemukan berbagai teknik penggambaran yang memiliki kemiripan dengan teknik-teknik yang biasa dipergunakan dalam fotografi, yaitu perpindahan pandangan pengamat, perpindahan dan/atau keajegan posisi pengamat, ketepatan dan ketajaman objek, sifat statis dan visual objek, serta ketidaksejajaran latar objek.
\end{abstract}

Kata kunci: realisme, deskripsi, fotografi 


\section{PENDAHULUAN}

Dalam kurun waktu pertengahan abad ke-19 hingga pertengahan abad ke-20, kebiasaan melihat suatu objek telah berubah secara radikal dibandingkan dengan abadabad sebelumnya. Perubahan ini terutama dihantarkan oleh fotografi, sebuah temuan teknologi dalam bidang perekaman visual dari ilmuwan asal Prancis bernama Louis Jacques Mandé Daguerre (1839). Alexander von Humboldt menamakan gambar-gambar yang dihasilkan, daguerreotypien, sebagai benda-benda yang tergambar seperti aslinya (dalam: Ogorka, 2005:24).

Temuan ini dianggap sebagai temuan terspektakuler pada abad ke-19. Sejak saat itu, minat masyarakat terhadap penemuan baru ini sangat besar. Fotografi dianggap dapat memenuhi kebutuhan manusia untuk meniru realita sesuai aslinya dan menawarkan kepada masyarakat untuk ke luar dari anonimitas melalui potret pribadi atau kelompok (Krauss, 2000:159).

Di bidang kesusastraan, terutama kesusastraan Jerman, hampir tidak ada reaksi terhadap munculnya temuan baru ini. Meskipun demikian, medium ini dibahas secara pribadi di dalam berbagai kesempatan. Dalam artikel Wilhelm Raabes Welt und Werk in Bildern (1931), Wilhelm Raabe menggambarkan bagaimana fotografi telah menemani perjalanan hidupnya. Rangkaian gambar dalam artikel ini diawali dengan foto Raabe pada saat ia menulis novel Chronik der Sperlingsgasse (1855). Kemudian terdapat pula sederetan foto Raabe dan keluarganya pada saat pernikahan dan perayaan ulang tahunnya yang ke-70. Raabe, terutama di saat-saat terakhir hidupnya, terlihat sangat suka dipotret.

Erwin Koppen, dalam bukunya yang berjudul Literatur und Photographie (Krauss, 2000:152), menyatakan bahwa hingga akhir abad ke-19, hanya ada sepuluh pengarang karya sastra berbahasa Jerman yang menjadikan fotografi sebagai bahan cerita. Di dalam karya-karya tersebut, fotografi muncul secara eksplisit melalui kata fotografi. Meskipun demikian, Krauss menyatakan dalam bukunya Photographie und Literatur. Zur photographischen Wahrnehmung in der deutschsprachigen Literatur des neunzehnten Jahrhunderts (2000) bahwa fenomena fotografis dalam karya-karya sastra dapat juga dirasakan dalam teks-teks yang tidak menyebutkan kata tersebut. Pernyataan ini didukung dengan telah adanya beberapa tulisan yang menghubungkan kedua bidang ini. Ada dua penulis yang membahas sejarah fotografi dari sudut pandang ilmu sastra. Mereka adalah Heinz Buddemeier dengan disertasinya Panorama, Diorama, Photographie (1970) dan Marianne Kesting dengan esai pendeknya Die Diktatur der Photographie (1980).

Munculnya bahasan yang mengaitkan sastra dan fotografi ini sangat menarik untuk diteliti lebih lanjut. Terutama dalam karya-karya sastra yang dihasilkan pada masa realisme, salah satu pembangunnya, yaitu deskripsi, berperan untuk menghasilkan gambar melalui media bahasa. Adapun fotografi, seperti halnya seni lukis, juga menghasilkan gambar melalui alat yang dinamakan kamera.

Kata-kata 'realisme', 'realis', dan 'realistis' merupakan kata-kata yang bukan hanya dipergunakan di dalam bahasa sehari-hari, melainkan juga di dalam bahasa ilmu pengetahuan, seperti ilmu filsafat, ilmu sejarah, ilmu bahasa, musik, seni, dan terutama ilmu kesusastraan. Di dalam bahasa sehari-hari, realisme menandai suatu sikap yang memiliki tujuan khusus untuk menggambarkan sesuatu yang nyata, objektif, dan masuk akal. Di dalam ilmu kesusastraan, realisme adalah kata yang berlaku internasional dan karenanya dapat dimaknai secara universal di berbagai negara. Menurut Träger (1986:422), istilah realisme secara umum selalu dihubungkan dengan istilah pencerminan dan kebenaran. Istilah ini menandai 
periode kesusastraan Jerman antara tahun 1830 dan 1880. Realisme berusaha untuk menjadi penghubung dan penengah dari nilai-nilai yang terdapat antara romantik (penekanan terhadap subjektivitas dan fantasi) dan naturalisme (penekanan terhadap kenyataan yang detail dari penggambaran yang buruk). Istilah realisme merupakan sintesa antara kenyataan dan keindahan. Sastra realisme ingin menggambarkan kenyataan melalui media bahasa. Hubungan dengan kenyataan dari sastra realistis abad ke-19 ini terwujudkan terutama melalui penggambaran kondisi kemasyarakatan pada zamannya. Oleh karenanya, kata Widerspiegelung (pencerminan/referensi) merupakan kata yang sangat penting bagi sastra masa ini. Dalam kesusastraan Jerman, misalnya, ada dua momentum penting yang sangat berpengaruh terhadap perubahan situasi historis, politis, kejiwaan, dan kesusastraan Jerman, yaitu kegagalan revolusi sosial politik tahun 1848/49 dan kemajuan industri serta ekonomi pada sekitar tahun 1850-an.

Bertolt Brecht menyatakan bahwa realistis dan detail adalah aspek-aspek yang harus hadir dalam karya sastra masa realisme. Keterangan tempat dan waktu yang tepat atau penggambaran rumah dan pakaian merupakan hal-hal yang harus diperhatikan oleh para realis (Aust, 2000:34). Meskipun demikian, hubungan antara tiruan dengan yang ditiru ini tidak boleh dipandang sebagai sebuah kopi mekanis (Fontane, ed. Plumpe, 2000:147).

Prestasi terpenting dalam kesusastraan masa realisme terletak dalam bidang prosa, terutama roman dan novel. Hal ini disebabkan oleh kesempatan yang diberikan oleh jenis-jenis karya sastra ini untuk merefleksikan kejadian-kejadian historis dan sosial pada masanya (Sengle, dalam Aust, 2000:73). Pada periode kesusastraan ini, salah satu unsur pembangun karya sastra, yaitu deskripsi, menempati posisi penting dan tidak hanya berfungsi untuk menggambarkan benda-benda, melainkan juga kondisi kemasyarakatan pada jamannya. Dalam kamus Duden, Deutsches Universalwörterbuch (Drosdowski, 1989:242), mendeskripsikan adalah: "etwas ausführlich, im einzelnen mit Worten wiedergeben, schildern, darstellen, erklären" (menceritakan kembali, melukiskan, menggambarkan, menjelaskan sesuatu satu persatu secara lengkap). Persamaan antara deskripsi dalam bahasa sehari-hari dan dalam ilmu pengetahuan adalah bahwa keduanya ingin menceritakan kembali apa yang dilihat dan ditangkap dengan tepat, eksak, dan lengkap, seperti yang dapat diamati oleh manusia, misalnya deskripsi perjalanan, pemandangan alam, orang, atau perjalanan hidup.

Dalam bidang kesusastraan dan estetik, deskripsi juga memiliki ciri-ciri seperti yang telah disebutkan sebelumnya. Meskipun demikian, deskripsi dalam karya sastra dibedakan dari deskripsi dalam bidang lainnya dalam hal fungsinya. Dalam kesusastraan, deskripsi didefinisikan sebagai berikut:

Eine Beschreibung ist die kunstvolle [a] sprachliche Darstellung [b] äußerlich sichtbarer Elemente eines Gesamtbildes (Mensch, Gegenstand, Ort usw.) [c] durch Poträtieren erkennbarer Züge, vollständiges Aufzählen aller Details oder pointiertes Herstellen wesentlicher Merkmale. Beschreibung ist die Kunst, mit Worten zu malen oder die Technik, mit Worten [d] einen bildlichen Eindruck beim Zuhörer bzw. Leser hervorzurufen (Ueding, 1992:1495).

Deskripsi adalah [a] penggambaran melalui bahasa yang penuh corak seni dari [b] elemen-elemen keseluruhan yang tampak dari luar (manusia, benda, tempat, dst.) [c] melalui pemotretan, penghitungan yang lengkap dari semua detail atau pemroduksian ciri-ciri khusus secara tajam. Deskripsi adalah seni melukis dengan kata-kata atau teknik [d] untuk membangkitkan kesan bergambar kepada pendengar atau pembaca melalui kata-kata.

Banyak ilmuwan yang menyibukkan diri dengan sifat-sifat khusus fotografi. Heinz Buddermeier, dalam bukunya Das Foto. Geschichte und Theorie der Fotografie als 
Grundlage eines neuen Urteils (1981), dan Erwin Koppen, dalam bukunya yang berjudul Literatur und Photographie, über Geschichte und Thematik einer Medienentdeckung (1987), mengemukan sifat-sifat fotografi yang $\mathrm{cu}-$ kup informatif, mudah untuk dipahami, dan berkonsentrasi pada konsep fotografi abad ke-19 (Daguerreotypie). Dalam bukunya, Buddermeier membahas perbedaanperbedaan antara pengamatan objek secara langsung oleh pancaindera (mata) dengan pengamatan objek melalui fotografi yang dilakukan jika kita mengarahkan kamera ke objek pada saat pemotretan. Lain halnya dengan Buddemeier, sifat-sifat fotografi yang diungkapkan oleh Koppen dikaitkan dengan unsur-unsur yang membedakan foto dari lukisan.

Adapun sifat-sifat fotografi menurut Buddemeier dan Koppen (Krauss, 2000:5972) adalah sebagai berikut: Ausschnitt der wirklichkeit 'potongan realita' yaitu keterbatasan fotografi untuk meniru satu potongan dari objeknya; Schärfenbereich 'bidang ketajaman' yaitu kemampuan fotografi untuk menangkap objek-objek yang tersebar dalam jarak yang berbeda-beda dari pengamatnya dalam satu bidang gambar dan menirunya dengan ketajaman yang sama; Verkleinerung der Natur 'pengecilan alam' yaitu kemampuan fotografi untuk memperkecil objeknya; Immobilisierung 'imobilisasi' yaitu keterbatasan fotografi untuk mereproduksi objek-objek bergerak; Beschränkung auf das Sehen 'pembatasan pada penglihatan' yaitu keterbatasan fotografi untuk mereproduksi objek-objek non visual; Privilegierter Beobachter-standpunkt 'posisi pengamat yang istimewa' yaitu kemampuan fotografi untuk menangkap objeknya dari posisi yang diinginkannya; Genauigkeit 'ketepatan' yaitu kemampuan fotografi untuk meniru objeknya dengan sangat detil; dan (h) Perspektive 'perspektif' yaitu kemampuan fotografi untuk menghadirkan objeknya dalam sebuah perspektif ruang.
Hal yang ingin dikaji lebih mendalam adalah bagaimana teknik-teknik fotografis dimunculkan dalam karya-karya sastra pada masa itu. Untuk mendukung penelitian ini dianalisis sebuah novel berjudul L'Adultera karya Theodor Fontane. Karya ini dipilih berdasarkan berbagai pertimbangan. Pertama, novel L'Adultera ditulis pada masa realisme (sekitar pertengahan abad ke-19), yaitu pada masa fotografi ditemukan. Novel ini bercerita tentang kehidupan kaum borjuis di Jerman pada abad ke-19. Fontane menjadikan sebuah skandal yang menggemparkan kota Berlin pada akhir tahun 1874 sebagai bahan ceritanya. Kedua, pengarangnya, yaitu Theodor Fontane, termasuk ke dalam salah satu penulis terpenting pada masa ini. Dalam sepuluh tahun terakhir kehidupannya, Fontane meraih puncak keberhasilannya sebagai penulis roman. Di dalam roman-romannya, Fontane banyak menggambarkan situasi dan konflik masyarakat pada masanya. Oleh karenanya, roman-romannya dikenal dengan sebutan Gesellschaftsroman (roman masyarakat). Ketiga, di dalam karya ini terdapat bagian-bagian teks yang dipenuhi oleh deskripsi yang menghadirkan kepada pembacanya kesan-kesan bergambar yang diasumsikan memiliki kesejajaran dengan teknik-teknik dalam fotografi. Tujuan penelitian ini adalah untuk mengidentifikasikan deskripsi-deskripsi yang muncul dalam karya tersebut dan mengkaji, bagaimana kriteria-kriteria fotografi direpresentasikan dalam deskripsi-deskripsi tersebut.

\section{METODE}

Metode yang digunakan dalam kajian ini adalah metode formal dan metode deskriptif analitik. Metode formal adalah analisis dengan mempertimbangkan aspekaspek formal, yaitu unsur-unsur karya sastra (Ratna, 2009:49), sedangkan metode deskriptif analitik dilakukan dengan cara 
mendeskripsikan fakta-fakta yang kemudian disusul dengan analisis (Ratna, 2009:53).

\section{HASIL DAN PEMBAHASAN}

Dalam beberapa bab novel L'Adultera ditemukan adanya potongan-potongan teks yang mengarah pada deskripsi. Hadirnya deskripsi-deskripsi ini dapat dikenali melalui ciri-ciri berikut ini: media yang digunakannya adalah bahasa, objek-objek yang dideskripsikannya dapat ditangkap oleh panca indra, metode deskripsinya adalah penggambaran tentang objeknya secara tepat, eksak, dan lengkap, serta efek deskripsinya adalah kesan bergambar kepada pembacanya. Pada setiap bab yang menghasilkan deskripsi akan diamati terlebih dahulu bagaimana alur utamanya, siapa tokoh-tokoh yang berperan, dialogdialog apa yang menyertainya, dan kapan deskripsi-deskripsi dimunculkan. Khusus pada deskripsinya, akan diuraikan lebih lanjut, apakah alur atau dialog antartokoh disisipkan ke dalam deskripsi tersebut. Selanjutnya, akan diuraikan, objek-objek apa saja yang hadir dalam setiap deskripsi. Penamaan setiap deskripsi didasarkan pada penyebutan yang muncul secara eksplisit dalam judul setiap bab dan/atau kesan bergambar yang ditimbulkan melalui deskripsinya, meliputi Pasar Harian, Kamar Melanie, Ruang Makan, Kedai Kopi Löbbekes Kaffeehaus, dan Taman Vila. Dalam deskripsi-deskripsi terpilih terdapat berbagai penggambaran yang mendekati kriteria-kriteria yang terdapat dalam fotografi. Selanjutnya akan dikaji, bagaimana kriteria-kriteria yang terdapat dalam fotografi direpresentasikan dalam setiap deskripsi, dengan langkah-langkah berikut ini:

Kesejajaran dua kriteria fotografi potongan realita dan pengecilan alam dalam setiap deskripsi akan dikaji secara terpadu. Pemaduan ini didasarkan pada kesamaan prinsip di antara keduanya: Melalui lensa kamera kita tidak dapat melihat realita atau alam yang ada di sekitar kita secara keseluruhan, melainkan hanya potongan atau bagian kecil darinya. Artinya, dari satu posisi, teknik fotografi hanya memiliki kemampuan untuk mereproduksi objekobjek tertentu dalam satu kali pemotretan. Untuk menangkap objek-objek yang tersebar atau terhalang oleh objek-objek pembatas, seorang pengamat harus mengarahkan kameranya untuk ke dua kalinya atau melakukan perpindahan posisi. Berdasarkan hal-hal di atas, dalam analisis ini akan diamati secara garis besar posisi objekobjeknya. Jika dalam deskripsi dihadirkan objek-objek yang tidak dapat ditangkap oleh kamera dalam satu kali pemotretan, akan dikaji lebih lanjut kehadiran ungkapanungkapan pemisah dan/atau ungkapanungkapan yang menandai perubahan posisi pengamat. Kesetaraan deskripsi dengan kedua kriteria fotografi potongan realita dan pengecilan alam dapat dikenali, jika objek-objek yang berada di luar jangkauan kamera diiringi dengan ungkapan-ungkapan penanda perubahan pandangan atau perubahan posisi pengamat.

Kemiripan teknik fotografi posisi pengamat yang istimewa dalam setiap deskripsi dilakukan berdasarkan kajian terhadap kemunculan ungkapan-ungkapan yang menandai posisi para pengamat. Jika dalam deskripsi, objek-objek dalam jangkauan pandangan kamera dihadirkan tanpa melakukan perubahan posisi, maka deskripsi tersebut memiliki kesetaraan dengan kriteria fotografi posisi pengamat yang istimewa.

Dalam setiap deskripsi, kesetaraan dua kriteria fotografi ketepatan dan bidang ketajaman akan dikaji secara terpadu. Keduanya memiliki keterkaitan yang erat dalam hal berikut ini: Teknik fotografi memiliki kemampuan untuk mereproduksi objekobjek yang tepat (detail) dan tajam dalam gambar. Jika dalam deskripsi, objek-objek 
dihadirkan dengan detail hingga menghasilkan ketajaman objek dalam berbagai hal, maka deskripsi tersebut memiliki kesetaraan dengan kedua kriteria fotografi ini.

Kemiripan kriteria fotografi imobilisasi akan dikaji melalui kehadiran gerakan objek-objek dalam setiap deskripsi. Kesetaraan deskripsi dengan kriteria fotografi ini akan dikenali, jika seluruh objek dihadirkan dalam bentuk statis.

Pada saat mengamati sebuah gambar fotografis, seseorang hanya melibatkan indera penglihatannya saja. Artinya, objekobjek yang hadir di hadapannya, hanya dapat dilihat, tetapi tidak dapat didengar, dicium, atau dirasakan. Untuk mengetahui, bagaimana kriteria fotografi pembatasan pada penglihatan dipergunakan dalam setiap deskripsi, akan diamati kembali berbagai kata atau frasa yang menyertai setiap objeknya. Kesetaraan deskripsi dengan kriteria fotografi ini dapat dikenali, jika kata-kata atau frasa-frasa penyerta objek-objeknya hanya mengarah pada sisi visualnya.

Sebuah gambar fotografis setidaknya terdiri dari dua latar berbeda. Dalam setiap deskripsi, kesetaraan dengan kriteria fotografi ini dapat dikenali jika objek-objeknya dihadirkan pada posisi tak sejajar.

Dalam tulisan ini, analisis hanya akan dilakukan pada satu deskripsi saja, yaitu deskripsi tentang pasar harian. Deskripsi tentang pasar harian dimunculkan dalam potongan teks berikut ini:

Handlung: Und dabei stand Melanie von ihrem hochlenigen Stuhl auf, ..., und trat an das große Mittelfenster.

Beschreibung: Unten bewegte sich das bunte Treiben eines Marktages, dem die junge Frau gern zuzusehen pflegte. Dicht an der Kirchentür, an einem kleinen, niedrigen Tische, saß ein Mütterchen, das ausgelassenen Honig in großen und kleinen Gläsern verkaufte, die mit ausgezacktem Papier und einem roten Wollfaden zugebunden waren. Ihr zunächst erhob sich eine Wildhändlerbude, deren sechs aufgehängte Hasen mit traurigen Gesichtern zu Melanie hinübersahen, während in Front der Bude (das erfrorene Gesicht in einer Kapuze) ein kleines
Mädchen auf und ab lief und ihre Schäfchen, wie zur Weihnachtszeit, an die Vorübergehenden feilbot. Über den ganzen aber lag ein grauer Himmel, und ein paar Flocken federten und tanzten, und wenn sie niederfielen, wurden sie vom Luftzuge neu gefaßt und wieder in die Höhe gewirbelt. (hlm. 7-8)

Alur: Dan pada saat itu, Melanie beranjak dari kursi bersandaran tinggi, ..., dan melangkah menuju jendela tengah yang besar. Deskripsi: Di bawah berlangsung kegiatan yang beraneka ragam dari pasar harian, pasar yang senang diamati oleh wanita muda itu. Di dekat pintu gereja, pada sebuah meja yang kecil dan pendek, duduk seorang ibu berbadan kecil yang menjual madu yang dibiarkan mengalir dalam gelasgelas besar dan kecil yang terikat dengan kertas bergerigi dan sebuah tali wol berwarna merah. Yang menarik perhatiannya untuk pertama kali adalah sebuah toko penjual binatang yang keenam kelincinya tergantung dan menatap Melanie dengan wajah-wajah sedih, sementara di depan toko, (wajah kedinginan dalam sebuah topi lancip) seorang gadis kecil berjalan ke sana ke mari dan menawarkan domba-domba kecilnya, seperti pada hari Natal, kepada orang-orang yang berlalu lalang. Di atas keseluruhan, langit kelabu dan beberapa bulu burung rontok dan menari, dan bulubulu yang berjatuhan ditangkap angin dan diputar-putarkan kembali ke ketinggian.

Deskripsi tentang pasar harian terdapat di bab ke-2, berjudul sama dengan judul novel ini, yaitu L'Adultera. Alur utamanya terjalin melalui dialog antara Melanie dan suaminya saat sarapan pagi. Salah satu hal yang diperbincangkan saat itu adalah sebuah lukisan bernama L'Adultera. Mahakarya pelukis Italia bernama Tintoretto ini, dilihat suaminya pada saat kunjungannya ke Venesia. Ia lalu meminta temannya, Salviati, untuk membuatkan tiruannya. Di tengah-tengah perbincangan seputar lukisan tersebut, disisipkan deskripsi tentang pasar harian, yaitu pasar yang terletak berdekatan dengan tempat tinggal keluarga van der Straaten di kota.

Deskripsi diawali dengan kegiatan yang beraneka ragam di pasar harian. Objek-objek yang dihadirkan dalam deskripsi adalah Kirchentür 'pintu gereja', Tische 'meja', Müt- 
terchen 'ibu berbadan kecil', Honig 'madu', Gläser 'gelas-gelas', Papier 'kertas', Wollfaden 'tali wol', Wildhändlerbude 'toko penjual binatang', Hasen 'kelinci-kelinci', Mädchen 'gadis', Schäfchen'domba-domba', Vorübergehenden' orang-orang yang berlalu lalang'. Selain objek-objek tersebut, narator menghadirkan dalam deskripsinya objek-objek yang berada di atas pasar harian, yaitu Himmel 'langit' dan Flocken 'bulu-bulu burung'. Deskripsi tidak diselingi oleh alur atau dialog.

Dalam deskripsi, objek-objek yang berada di pasar harian dan bagian atas pasar harian tidak dapat ditangkap dalam satu kali pemotretan. Objek-objek di pasar harian berada di bawah dan di posisi yang tersebar dari objek-objek yang berada di bagian atas pasar harian. Untuk dapat menangkap seluruh objek, seorang pengamat tidak harus melakukan perpindahan posisi, tetapi harus mengarahkan kameranya ke bawah dan ke atas. Dalam deskripsi perpindahan pandangan ini ditandai melalui ungkapan berikut ini:

(1) Unten bewegte sich das bunte Treiben eines Markttages, .... Über den ganzen aber lag ein grauer Himmel ....

Di bawah berlangsung kegiatan yang beraneka ragam dari pasar harian, .... Di atas keseluruhan, langit kelabu ....

Preposisi unten 'di bawah' dan über (den ganzen) 'di atas (keseluruhan)', menandai perubahan pandangan pengamat dari bawah ke atas. Ke hadapan pembaca hadir dua kesan bergambar, yaitu kesan bergambar tentang pasar harian dan langit di atas pasar harian.

Melanie adalah pengamat objek-objek dalam deskripsi. Dengan bantuan kamera, Melanie tidak perlu melakukan perpindahan posisi untuk dapat menangkap seluruh objek yang dihadirkan dalam deskripsi. Dalam deskripsi, nomina Mittelfenster 'jendela tengah' dalam ungkapan berikut ini:

(2) Und dabei stand Melanie von ihrem hochlenigen Stuhl auf, ..., und trat an das große Mittelfenster.
Dan pada saat itu, Melanie beranjak dari kursi bersenderan tingginya, ..., dan melangkah menuju jendela tengah yang besar, menandai posisi Melanie yang tengah berdiri pada salah satu jendela rumahnya. Hingga akhir deskripsi tidak ada ungkapanungkapan penanda perubahan posisi pengamat. Artinya, Melanie mengamati seluruh objek dalam deskripsi dari posisi yang sama.

Dalam deskripsi, ketepatan dan ketajaman dalam fotografi ditunjukkan salah satunya oleh objek Mütterchen 'ibu berbadan kecil' berikut ini:

(3) Dicht an der Kirchentür, an einem ... Tische, saß ein Mütterchen, das ... Honig in ... Gläsern verkaufte.

Di dekat pintu gereja, pada sebuah meja ..., duduk seorang ibu berbadan kecil yang menjual madu ... dalam gelas-gelas ....

Pada objek ini, morfem -chen bermakna diminutif memperjelas ukuran (tubuh), sedangkan verba saß 'duduk' dan verkaufte 'menjual' memperjelas aktifitas objek. Preposisi dicht an 'di dekat' dan an 'pada', meskipun tidak mengacu secara langsung pada objek ibu, menandai (kedekatan) posisi objek ini terhadap dua objek lainnya, yaitu Kirchentür 'pintu gereja' dan Tische 'meja'. Seluruh kata yang menyertai objek ibu ini menandai juga sifat statis dan visual objek seperti dalam teknik fotografi.

Perspektif dalam teknik fotografi ditunjukkan salah satunya melalui ungkapan berikut ini:

(4) Dicht an der Kirchentür, an einem ... Tische, saß ein Mütterchen, das ... Honig in ... Gläsern verkaufte, ....

Di dekat pintu gereja, pada sebuah meja ..., duduk seorang ibu berbadan kecil yang menjual madu ... dalam gelas-gelas ....

Preposisi dicht an 'di dekat' menandai kesejajaran posisi antara objek Kirchentür 'pintu gereja' dengan objek Mütterchen 'ibu berbadan kecil'. Sementara itu, preposisi an 'pada' menandai posisi objek Tische 'meja' 
yang berada tepat di hadapan ibu. Pronomina penghubung das 'yang' dan preposisi in 'dalam' menandai kesejajaran posisi objek Honig 'madu' dan Gläser 'gelas-gelas' dengan meja. Dapat disimpulkan bahwa dua objek pertama (ibu dan pintu gereja) berada di belakang tiga objek lainnya (meja, madu, dan gelas-gelas). Ketidaksejajaran posisi objek-objek ini akan membentuk perspektif ruang seperti dalam sebuah gambar fotografis.

Ditinjau dari kriteria fotografi potongan realita, pengecilan alam, dan posisi pengamat yang istimewa, kehadiran ungkapanungkapan yang menandai perpindahan pandangan dari pasar harian ke bagian atas pasar harian dan keajegan posisi pengamat pada saat mengamati objek-objek di sekitarnya mengarah pada cara kerja yang sejalan dengan teknik pengambilan gambar.

Selain objek Mütterchen 'ibu berbadan kecil', seluruh objek lain dalam deskripsi dihadirkan dengan detail dan hadir ke hadapan pembaca dengan ketajaman yang berbeda-beda. Secara keseluruhan, ketepatan dan ketajaman objek-objek yang dihasilkan melalui deskripsi narator akan memiliki kesamaan dengan ketepatan dan ketajaman objek-objek yang dihasilkan oleh teknik fotografi.

Dalam deskripsi dihadirkan pula beberapa objek dengan gerakan yang menyertainya. Kualitas gerakan ini misalnya dihadirkan melalui ajektiva ausgelassen 'dibiarkan mengalir' atau verba auf und ab lief 'berjalan ke sana ke mari'. Objek yang berada di atas pasar harian, yaitu Flocken 'bulu-bulu burung' juga dihadirkan dengan gerakan yang menyertainya dan ditunjukkan melalui verba-verba seperti federten 'rontok' atau niederfielen 'berjatuhan'. Gerakan beberapa objek dalam kedua potongan deskripsi ini tidak dapat direproduksi ke dalam sebuah gambar fotografis.

Dalam deskripsi, potongan deskripsi tentang pasar harian dihadirkan sepenuh- nya secara visual. Sementara itu, dalam potongan deskripsi tentang langit di atas pasarharian, ditemukan pula penggambaranpenggambaran yang tidak dapat ditangkap secara visual. Verba tanzten 'menari' dan frasa wurden vom Luftzuge gefaßt 'ditangkap angin' merupakan ungkapan-ungkapan metaforis bagi objek Flocken 'bulu-bulu burung' dan menghadirkan kepada pembaca suasana-suasana yang tak dapat direproduksi ke dalam sebuah gambar fotografis.

Objek-objek dalam deskripsi berada di tiga latar yang berbeda. Objek-objek seperti Kirchentür 'pintu gereja' dan Mütterchen 'ibu berbadan kecil' berada di latar belakang, objek-objek seperti Tische 'meja' dan Honig 'madu' di latar tengah, dan objek-objek seperti Vorübergehenden 'orang-orang yang berlalu lalang' di latar depan. Ketidaksejajaran posisi objek-objek dalam deskripsi mengarah pada kesetaraan dengan kriteria fotografi perspektif.

\section{SIMPULAN}

Dalam novel L'Adultera, deskripsideskripsi yang dimunculkan oleh narator terbagi ke dalam tiga jenis latar, yaitu latar alam, interior, dan latar bangunan. Deskripsi tokoh tidak ditemukan sama sekali.

Dalam setiap deskripsi terdapat teknikteknik penggambaran yang memiliki kemiripan dengan teknik-teknik yang biasa dipergunakan dalam fotografi. Hal ini ditunjukkan melalui kehadiran ungkapanungkapan yang menandai perubahan pandangan atau posisi ketika seorang pengamat ingin menangkap objek-objek yang letaknya tersebar atau terpisah oleh objekobjek pembatas, keajegan posisi pengamat pada saat mengamati objek-objek yang berada dalam jangkauan pandangannya, identitas objek secara detail, tajam, statis, visual, dan berperspektif ruang.

Meskipun demikian, untuk menghadirkan objek-objek dalam deskripsi secara 
total, narator menghadirkan pula teknikteknik penggambaran yang berbeda dari teknik-teknik yang biasa dipergunakan dalam fotografi. Deskripsi objek dalam karya ini, misalnya, tidak hanya mengarah pada sifat statis objek-objeknya. Dalam kaitan ini, gerakan-gerakan dari beberapa objek turut dihadirkan dalam beberapa deskripsi. Selain itu, identitas beberapa objek tidak hanya dihadirkan secara visual, tetapi juga dengan bunyi, bau, atau rasa yang menyertainya. Hal-hal inilah yang menandai perbedaan di antara deskripsi dalam karya sastra dengan fotografi.

\section{Daftar Pustaka}

Aust, Hugo

2000 Literatur des Realismus. 3. Auflage. Stuttgart: J.B. Metzlersche Verlagsbuch handlung und Carl Ernst Poeschlel Verlag $\mathrm{GmbH}$.

Drosdowski, Günther (Hrsg.)

1989 Duden, Deutsches Universalwörter buch. 2., völlig neu bearb. u. stark erw. Aufl. Mannheim.
Fontane, Theodor

2000 L'Adultera. Stuttgart: Philipp Reclam. jun., GmbH \& Co.

Plumpe, Gerhard (Hrsg.)

2001 Theorie des bürgerlichen Realismus. Stuttgart: Philipp Reclam jun. GmbH \& Co.

Krauss, Rolf $\mathrm{H}$.

2000 Photographie und Literatur. Zur photographischen Wahrnehmung in der deutsch sprachigen Literatur des neunzehnten Jahrhunderts. Stuttgart: Hatje Cantz Verlag.

Träger, Claus

1986 Wörterbuch der Literaturwissenschaft. 1. Auflage. Leipizig: VEB Bibliographisches Institut.

Ogorka, Martha

2005 Literatur und Fotografie im 19. Jahrhundert. ISBN (E-Book): 978-3-63861339-2. dalam: http://www.grin.com /de/e-book/69346/lit eratur-und fotografie-im-19-jahrhundert [21/11/2009]. 